\title{
Análise de Políticas Públicas Inclusivas para Deficientes Intelectuais com Síndrome de Down
}

\section{Hadassa L. de Oliveira*, Lubienska C. L. Jaquiê Ribeiro}

\section{Resumo}

As políticas públicas inclusivas abordam a questão da garantia de direitos, se embasando na igualdade e na democratização de oportunidades para todos. No entanto, não se observa o cumprimento das políticas no cotidiano do público alvo dessas, já que uma mera observação evidencia o fato. Para tanto, conhecer quais políticas públicas inclusivas estão em vigor no Brasil cria o caminho para a verificação da efetividade prática na vida de jovens com deficiência intelectual. A partir disso, se conclui que são ainda pouco efetivas e que a educação ambiental pode ser uma ferramenta precursora na garantia de direitos a estes.

\section{Palavras-chave:}

Políticas Públicas, Educação Ambiental, Inclusão Social.

\section{Introdução}

É de conhecimento comum que o cotidiano e de uma pessoa com deficiência intelectual é no mínimo diferente das demais pessoas; quando visto mais de perto se identifica que além disso, é limitante e muito complicado. Em uma sociedade onde ser "diferente" é ser isolado a única garantia fica a cargo de políticas públicas que confiram direitos a estes dentro de sua realidade. Portanto, identificar quais são as políticas públicas inclusivas em vigor no Brasil e verificar se atendem efetivamente às necessidades de jovens com deficiência intelectual categorizada com a Síndrome de Down é o objetivo da presente pesquisa. Como desdobramento da análise destes é preciso responder também qual o impacto da não efetividade das políticas públicas inclusivas na vida desses jovens, além de incitar a reflexão: "as políticas públicas vigentes são realmente inclusivas?”.

\section{Resultados e Discussão}

Evidenciou-se ao longo da pesquisa bibliográfica a caracterização clara das políticas públicas do âmbito escolar, dito formal, e no âmbito não formal, fora da escola, de modo que as garantias de um indivíduo que frequente uma instituição de ensino se superam aos daquele que não a frequenta. Segundo a UNESCO, o Brasil é o que mais insere alunos com necessidades especiais em escolas na América Latina. Contudo, quando este, agora jovem, se depara com o início de uma vida adulta fora de uma instituição de ensino, se vê perdido e desamparado já que os profissionais que o assessoravam estão limitados aos muros da escola e o mundo aqui fora parece não estar preparado para ele. Embora 0 artigo $8^{\circ}$ da Lei Brasileira da Inclusão da Pessoa com Deficiência (Lei 13.146 de Julho de 2015) institua como dever do Estado, da sociedade e da família a efetivação dos direitos referentes à vida, à saúde, à sexualidade, [...] à habilitação, à educação, à profissionalização, ao trabalho entre tantos outros, na prática isso não acontece. Destacou-se essas categorias do artigo $8^{\circ}$ da Lei 13.146, por serem os mais ressaltados durante a etapa de observação dos jovens com deficiência intelectual categorizados com Síndrome de Down, por de fato não ocorrerem. A dificuldade de interação com outros jovens para criar uma vida social se mostrou fator limitante para o cumprimento da Lei mencionada que em seu artigo 14, parágrafo único, declara a conquista da autonomia e da participação social em igualdade de condições e oportunidades. A partir desta constatação, os demais estamentos seguem se comprometendo de igual forma, no profissional, no exercício da política ou mesmo na concretização do relacionamento amoroso. Checou-se, portanto, que a educação ambiental como ferramenta de reflexão e reconhecimento do indivíduo como parte do meio, permite o estreitamento desses aspectos da vida em sociedade, permitindo a aplicação prática do termo inclusão social.

\section{Conclusões}

Demonstra-se através da pesquisa que conhecer a situação da inclusão social garantida na política pública brasileira é fundamental para a análise crítica da vida prática do jovem com deficiência intelectual. A aplicação da mesma se mostrou pouco efetiva nos diversos estamentos da sociedade organizada, mesmo sendo uma garantia conferida em caráter de lei. A educação ambiental se mostrou uma ferramenta efetiva para alcançar bons resultados no processo crítico e analítico da inclusão social no país, pois correlaciona os assuntos do cotidiano e identifica o indivíduo como parte do meio ambiente em que está inserido. Conclui-se também, que a política pública de inclusão trata desse processo com bastante clareza, atendendo ao conceito da inclusão social em seu mais atual entendimento. Contudo, a execução da mesma nas instâncias da sociedade ainda se mostra muito excludente e segregativa.

\section{Agradecimentos}

Agradeço a melhor orientadora, competente e sensível, Lubienska Cristina Lucas Jaquiê Ribeiro pelo incentivo e interesse compartilhado ao longo da pesquisa. Ao Projeto Ecoedu Ambiental pelo encorajamento ao trabalho, acreditando que a pesquisa possa alcançar mudanças significativas para os jovens com que trabalham.

Brasil. Boletim UNESCO sobre Educação Inclusiva, 1998.

Brasil. Lei $\mathrm{n}^{\mathrm{o}} 13.146$, de 06 de julho de 2015. Institui a lei brasileira de inclusão da Pessoa com Deficiência (Estatuto da Pessoa com Deficiência). Brasília, DF. <Disponível em: http://www.planalto.gov.br/ccivil_03/_ato20152018/2015/lei/113146.htm> Acessado em: 10 de julho de 2018. 